Article

\title{
Fruit Yields Depend on Biomass and Nutrient Accumulations in New Shoots of Citrus Trees
}

\author{
Zihan Fan ${ }^{1, \dagger}$, Huaye Xiong ${ }^{1, \dagger}$, Yayin Luo ${ }^{1}$, Yuheng Wang ${ }^{1}$, Huanyu Zhao ${ }^{1,2}$, Wenli Li ${ }^{1}$, \\ Xinhua He ${ }^{1}\left(\mathbb{D}\right.$, Jie Wang ${ }^{1,2,3}$, Xiaojun Shi ${ }^{1,2,3,4}$ and Yueqiang Zhang $1,2,3,4, * \mathbb{D}$ \\ 1 College of Resources and Environment, Southwest University, Chongqing 400716, China; \\ f19961219@email.swu.edu.cn (Z.F.); woaisesero@email.swu.edu.cn (H.X.); \\ lyy123456@email.swu.edu.cn (Y.L.); wyh1996@email.swu.edu.cn (Y.W.); zhaohy@email.swu.edu.cn (H.Z.); \\ zmylw120@email.swu.edu.cn (W.L.); xinhua.he@uwa.edu.au (X.H.); mutouyu@swu.edu.cn (J.W.); \\ shixj@swu.edu.cn (X.S.) \\ 2 Interdisciplinary Research Center for Agriculture Green Development in Yangtze River Basin, \\ Southwest University, Chongqing 400716, China \\ 3 State Cultivation Base of Eco-Agriculture for Southwest Mountainous Land, Southwest University, \\ Chongqing 400716, China \\ 4 National Monitoring Station of Soil Fertility and Fertilizer Efficiency on Purple Soils, Southwest University, \\ Chongqing 400716, China \\ * Correspondence: zhangyq82@swu.edu.cn; Tel.: +86-1992-335-8234 \\ + These authors contributed equally to this work.
}

Received: 17 November 2020; Accepted: 16 December 2020; Published: 17 December 2020

\begin{abstract}
New shoots (including newly formed leaves and twigs) and fruits of citrus tree are key organs for present yield formation and flower differentiation in the next season, but the relationship between yield fluctuation and accumulations of major nutrients in new shoots and fruits of citrus tree is still unclear. Thus, to quantify the biomass and mineral nutrient accumulation in new shoots and fruits of citrus trees under varied yield levels has essential significance for rational fertilization and pruning management for citrus orchards. The purpose of this study was, therefore, to investigate the accumulation of nitrogen $(\mathrm{N})$, phosphorus $(\mathrm{P})$, potassium $(\mathrm{K})$, calcium $(\mathrm{Ca})$ and magnesium $(\mathrm{Mg})$, and the distribution of biomass in new shoots and fruits of citrus trees under low, medium and high-yield levels in each of eight orchards located in Chongqing, China. The results showed that substantial variation of fruit yield was observed in all eight orchards with an average yield of 15.0 (low), 30.9 (medium) and 60.1 (high) kg/plant. The averaged biomass of new shoots ranged from 1.59 to $2.51 \mathrm{~kg} / \mathrm{plant}$, which was significantly and positively correlated with fruit yield. Nutrient accumulation in leaves was generally highest among new organs, while more than half of $\mathrm{N}(52.70-71.4 \%), \mathrm{P}(66.5-80.4 \%)$ and K (68.9-85.9\%) accumulated in fruit. Fruit yields closely correlated with total amounts of major nutrients in new shoots. Furthermore, the nutrient requirements per unit of newly developed shoots and fruits were gradually decreased with increased yield, but the removed nutrients per ton of fresh fruit were almost stable, indicating that more nutrients were distributed into fruit tissues. Taken together, these findings are valuable for optimizing nutrient and pruning management in citrus orchards in China and other similar countries.
\end{abstract}

Keywords: yield level; new shoots; nutrient accumulation; fruit; nutrient harvest index

\section{Introduction}

Mineral elements are the vital material basis for fruit trees to obtain high yield and quality [1]. Therefore, numerous studies have reported that mineral nutrients play a vital role in citrus tree growth, fruit yield and quality formation [2,3]. For example, nitrogen $(\mathrm{N})$ and potassium $(\mathrm{K})$ are the two 
most accumulated nutrients in citrus fruits [4]; phosphate $(\mathrm{P})$ promotes the growth of citrus trees [5]; and calcium (Ca) reduces the effects of copper stress on citrus roots and leaves [6], magnesium $(\mathrm{Mg})$ deficiency induces swelling, cracking and lignification of leaf veins [7]. In addition, the alternate bearing phenomenon of citrus trees is also closely related to nutrient demand and distribution, which seriously affect the citrus yield [8,9]. Therefore, how to obtain sustained high yields is still unresolved [10-12].

In general, understanding and quantifying nutrient requirement is the key to citrus fertilization. Although citrus leaves account for only $21 \%$ of the above-ground biomass, they contain a high proportion (31-44\%) of above-ground nutrients [13]. Previous studies have shown that $\mathrm{N}$ in fertilizers is mainly distributed in citrus shoots, leaves and fruits [14] and citrus fruits have a high demand for microelement during development, and there is a strong linear relationship between dry matter yield and nutrient accumulation [4]. The new organs of citrus trees (annual leaves, twigs and fruits) are the most active parts of mineral nutrition, which are closely related to the formation of yield and lay the nutrient foundation for flowering and fruiting in the coming year $[4,15]$. In non-fruiting citrus trees, the concentration of $\mathrm{N}$ in the leaves of citrus in spring and summer tends to decrease, and half of the ${ }^{15} \mathrm{~N}$ annually absorbed by citrus is allocated to new organs [16]. In addition, applying a large amount of $\mathrm{N}$ fertilizer in spring can also significantly promote the growth of spring shoots and fruit yield of citrus [17]. Therefore, the new shoot of citrus is an essential nutrient-requiring organ and will contribute to later yield production.

However, previous studies have rarely involved the accumulation and distribution of dry matter and minerals in new shoots and fruits under different yield levels. China is one of the most important citrus producers, but the problems of low yield, excessive fertilization and alternate bearing exist. In short, it is necessary to quantify the new tissues' nutrient demand rule and establish a rational fertilization method critical to achieve high and stable yield, and high fruit quality in citrus plantations [18].

Therefore, in this study, the new shoots and fruits of citrus trees under different yield levels were collected under similar management and tree-age conditions. The accumulation and distribution of biomass and nutrients at these new shoots at various yield levels were then analyzed. We hypothesized that: (1) the accumulation of biomass and nutrients in the new shoots was the basis for the formation of citrus yield; (2) as the yield level increased, more nutrients were distributed in the fruit, which will reduce the vitality of the tree. This study could promote our understanding of relationships between citrus nutrients, particularly $\mathrm{N}$, and yields in the citrus new shoots for a sustainable citrus fruit production.

\section{Materials and Methods}

\subsection{Study Area}

The field experiment was conducted at the commercial orchard $\left(29^{\circ} 59^{\prime} 8^{\prime \prime} \mathrm{N}, 107^{\circ} 12^{\prime} 58^{\prime \prime} \mathrm{E}\right)$, located in Changshou, Chongqing City, China. The experimental site has a typical subtropical monsoon climate, with an average annual rainfall of $1000 \mathrm{~mm}$ ( $70 \%$ in summer). The annual average temperature is between 15 and $21^{\circ} \mathrm{C}$. The citrus plantation area is about 13,000 ha; the dominant variety is W. Murcott tangerine (Citrus reticulate L.) with a standard planting density of 900 plants per hectare. The average ages of these trees were about 8 years in 2018. The annual fertilization rates of the eight orchards were the same ( $\left.\mathrm{N}, 450 \mathrm{~kg} / \mathrm{ha} ; \mathrm{P}_{2} \mathrm{O}_{5}, 250 \mathrm{~kg} / \mathrm{ha} ; \mathrm{K}_{2} \mathrm{O}, 450 \mathrm{~kg} / \mathrm{ha}\right)$.

The citrus orchards soil at $0 \sim 20 \mathrm{~cm}$ depth had the following characteristics for the respective low-yield, medium-yield and high-yield orchards: total organic matter of 22.3, 20.9 and $18.9 \mathrm{~g} / \mathrm{kg}$; total $\mathrm{N}$ of 1.11, 1.90 and $1.15 \mathrm{~g} / \mathrm{kg}$; available-P of 21.4, 27.8 and $27.9 \mathrm{mg} / \mathrm{kg}$; available- $\mathrm{K}$ of 236, 244 and

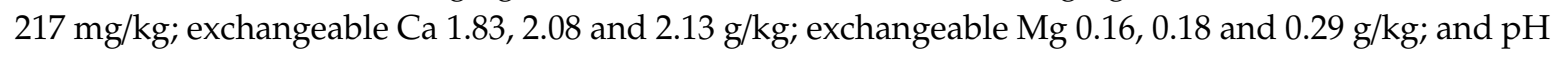
of $5.16,5.38$ and 5.33 (1:2.5 water).

\subsection{Experimental Design and Field Sample Collection}

The trees with middle yield level were firstly evaluated by averaged fruit loading in each of the eight orchards, and the trees with around half and double of the fruit loading were then defined as trees 
with low yield and high yield, respectively (Figure 1). Thus, a total of 24 trees were chosen from eight orchards, with eight trees of each yield-level as replicates. At the harvest stage in December 2018, all of the new organs including fruit, leaf and twig were separately collected (Figure A1). The fresh weights of the separated fruit, leaf and twig samples were recorded (Appendix A Table A1), and then subsamples were randomly collected for further process $[19,20]$. Leaves and branches collected from new shoots in spring, summer and autumn were used to calculate nutrient accumulations. The amounts of nutrient accumulations in plant tissues were calculated by biomass with nutrient concentrations.

(1) Nutrient accumulation in newly developed parts $=\sum\left(\mathrm{NBP}_{\mathrm{i}} \times \mathrm{C}_{\mathrm{i}}\right) . \mathrm{NBP}_{\mathrm{i}}$ is the biomass of the newly developed parts $i ; C_{i}$ is the nutrient concentration of $i$.

(2) Nutrient harvest index $=$ nutrient accumulation in fruits/total nutrient accumulation in newly developed parts $\times 100 \%$.

(3) Nutrient demand per unit of newly developed parts = nutrient accumulation in newly developed parts/fruit yield.

(4) Nutrient accumulation in new shoots = nutrient accumulation in leaves + nutrient accumulation in twigs.

(5) Nutrient demand per unit of fruits = nutrient accumulation in fruit/fruit yield.

(6) Nutrient demand in leaves (twigs) = nutrient accumulation in leaves (twigs)/biomass of leaves (twigs).

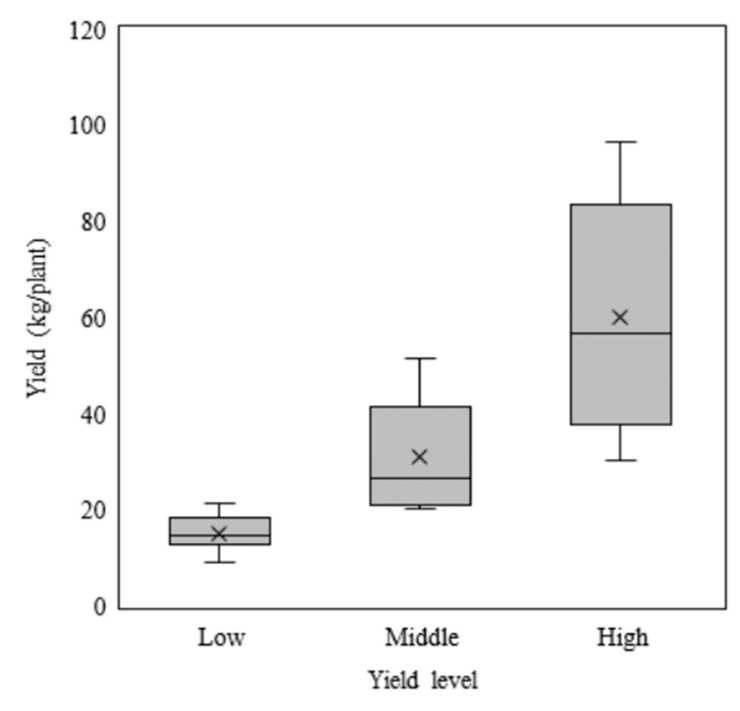

Figure 1. The yield of citrus trees in different orchards.

\subsection{Determination of Nutrient Elements in Leaves, Shoots and Fruits}

These subsamples were washed by tap water, rinsed in deionized water and oven-dried at $65{ }^{\circ} \mathrm{C}$ for $72 \mathrm{~h}$ until a constant weight was determined as the dry weight (DW). Meanwhile, $2.00 \mathrm{~g}$ of homogenized fruit samples and $0.20 \mathrm{~g}$ of other dried samples were weighed for digestion with $\mathrm{H}_{2} \mathrm{SO}_{4}-\mathrm{H}_{2} \mathrm{O}_{2}$, and the $\mathrm{N}$ concentration in the digestive juice was determined by the trace Kjeldahl method [21]. The concentrations of $\mathrm{P}, \mathrm{K}, \mathrm{Ca}, \mathrm{Mg}$ in the digested solution were determined by an inductively coupled plasma optical emission spectroscopy (ICP-OES). Fruit samples were determined with fresh fruits, and $2.00 \mathrm{~g}$ of homogenized fruit samples was digested with $\mathrm{HNO}_{3}-\mathrm{H}_{2} \mathrm{O}_{2}$ in a microwave. In addition, they were also ground in a stainless-steel mill, and $0.20 \mathrm{~g}$ dried samples (leaves or twigs) was digested with $\mathrm{HNO}_{3}-\mathrm{H}_{2} \mathrm{O}_{2}$ in a microwave accelerated reaction system [22].

\subsection{Statistical Analysis}

All data were analyzed using the analysis of variance (ANOVA), and significant differences among treatments were compared by the Least Significant Difference (LSD) test at $p<0.05$ using the Statistical 
Analysis System (SAS) 8.0. The different letters in the table represent significant differences among yield-levels. Excel 2010 was used to draw figures.

\section{Results}

\subsection{Biomass and Nutrient Accumulations in Citrus Shoots and Fruits under Different Yield Levels}

To determine whether citrus orchards with different yield levels affect the growth of new shoots, shoot biomass and nutrient accumulation were measured (Tables 1-3). Under different yield levels, there were significant differences in biomass and nutrient concentrations of citrus shoots and fruits. The total biomass production was higher in fruits than in new shoots. The fruit biomass under low-yield, middle-yield and high-yield orchards were $2.98,6.27$ and $13.00 \mathrm{~kg} / \mathrm{plant}$, respectively, accounting for $65.21 \%, 78.38 \%$ and $83.87 \%$ of the total biomass of new organs. Leaves and twigs accounted for $21.00 \sim 11.55 \%$ and $13.79 \sim 4.6 \%$ of the total biomass (Table 1). New shoots had the highest accumulation of $\mathrm{Ca}$, followed by $\mathrm{N}, \mathrm{K}, \mathrm{Mg}$ and $\mathrm{P}$ (Table 3). With the increase in yield level, the main accumulation of $\mathrm{N}(52.70-71.4 \%), \mathrm{P}(66.5-80.4 \%), \mathrm{K}(68.9-85.9 \%)$ and $\mathrm{Mg}(40.95-61.0 \%)$ was mainly in fruits, while Ca was mainly in new shoots (70.88-79.27\%). However, accumulations of $\mathrm{N}(47.24-28.57 \%), \mathrm{P}(33.53-19.6 \%)$, $\mathrm{K}(44.95-14.08 \%), \mathrm{Ca}(79.30-70.88 \%)$ and $\mathrm{Mg}(59.05-38.94 \%)$ decreased with the increase in yield level in the new shoots. Under different yield levels, there were significant differences in the accumulation of nutrients in the new shoots of citrus trees, i.e., low yield $<$ middle yield $<$ high yield (Table 3 ).

Table 1. The biomass in new organs of citrus trees with respect to yield level. The different letters $(a, b)$ in the table represent significant differences $(p<0.05)$ among yield-levels.

\begin{tabular}{cccccc}
\hline Yield & $\begin{array}{c}\text { Leaves } \\
\text { (kg/Plant) }\end{array}$ & $\begin{array}{c}\text { Twigs } \\
\text { (kg/Plant) }\end{array}$ & $\begin{array}{c}\text { Non-Fruit Part } \\
\text { (kg/Plant) }\end{array}$ & $\begin{array}{c}\text { Fruits } \\
\text { (kg/Plant) }\end{array}$ & $\begin{array}{c}\text { Total } \\
\text { (kg/Plant) }\end{array}$ \\
\hline Low & $0.96^{\mathrm{b}}$ & $0.63^{\mathrm{a}}$ & $1.59^{\mathrm{a}}$ & $2.98^{\mathrm{b}}$ & $4.57^{\mathrm{b}}$ \\
Middle & $1.2^{\mathrm{ab}}$ & $0.53^{\mathrm{a}}$ & $1.73^{\mathrm{a}}$ & $6.27^{\mathrm{b}}$ & $8.00^{\mathrm{b}}$ \\
High & $1.79^{\mathrm{a}}$ & $0.72^{\mathrm{a}}$ & $2.51^{\mathrm{a}}$ & $13.00^{\mathrm{a}}$ & $15.50^{\mathrm{a}}$ \\
\hline
\end{tabular}

Table 2. Nutrient concentrations of leaves, twigs and fruits under different yield levels. The different letters $(\mathrm{a}-\mathrm{c})$ in the table represent significant differences $(p<0.05)$ among yield-levels.

\begin{tabular}{|c|c|c|c|}
\hline \multirow{2}{*}{ Yield-Level } & Leaves & Twigs & Fruits \\
\hline & (g/kg) & $(g / k g)$ & $(\mathrm{g} / \mathrm{kg})$ \\
\hline \multicolumn{4}{|c|}{ Nitrogen in all seasons } \\
\hline Low & $19.7^{\mathrm{a}}$ & $8.97^{\mathrm{a}}$ & $8.88^{a}$ \\
\hline Middle & $20.3^{a}$ & $8.10^{a b}$ & $9.38^{a}$ \\
\hline High & $20.6^{\mathrm{a}}$ & $7.58^{b}$ & $8.47^{\mathrm{a}}$ \\
\hline \multicolumn{4}{|c|}{ Phosphorus in all seasons } \\
\hline Low & $1.46^{\mathrm{b}}$ & $1.22^{c}$ & $1.44^{\mathrm{a}}$ \\
\hline Middle & $1.52^{\mathrm{a}}$ & $1.37^{\mathrm{b}}$ & $1.39^{a}$ \\
\hline High & $1.52^{\mathrm{ab}}$ & $1.60^{\mathrm{a}}$ & $1.29^{a}$ \\
\hline \multicolumn{4}{|c|}{ Potassium in all seasons } \\
\hline Low & $9.59^{\mathrm{a}}$ & $5.94^{\mathrm{a}}$ & $9.66^{a}$ \\
\hline Middle & $8.69^{b}$ & $5.36^{\mathrm{b}}$ & $9.63^{a}$ \\
\hline High & $9.57^{\mathrm{a}}$ & $4.37^{\mathrm{c}}$ & $9.48^{a}$ \\
\hline \multicolumn{4}{|c|}{ Calcium in all seasons } \\
\hline Low & $22.2^{b}$ & $5.75^{\mathrm{a}}$ & $2.09^{a}$ \\
\hline Middle & $31.1^{\mathrm{a}}$ & $5.85^{\mathrm{a}}$ & $1.93^{\mathrm{a}}$ \\
\hline High & $34.4^{\mathrm{a}}$ & $5.92^{\mathrm{a}}$ & $2.00^{a}$ \\
\hline \multicolumn{4}{|c|}{ Magnesium in all seasons } \\
\hline Low & $2.06^{\mathrm{a}}$ & $0.99^{\mathrm{a}}$ & $0.60^{\mathrm{a}}$ \\
\hline Middle & $2.18^{\mathrm{a}}$ & $0.92^{\mathrm{a}}$ & $0.56^{\mathrm{a}}$ \\
\hline High & $2.27^{\mathrm{a}}$ & $0.87^{\mathrm{a}}$ & $0.58^{a}$ \\
\hline
\end{tabular}


Table 3. Nutrient accumulations in leaves, twigs and fruits, and nutrient harvest indexes under different yield levels. The different letters $(\mathrm{a}-\mathrm{c})$ in the table represent significant differences $(p<0.05)$ among yield-levels.

\begin{tabular}{|c|c|c|c|c|c|}
\hline Yield-Level & $\begin{array}{l}\text { Leaves } \\
\text { (g/Plant) }\end{array}$ & $\begin{array}{l}\text { Twigs } \\
\text { (g/Plant) }\end{array}$ & $\begin{array}{l}\text { New Shoots } \\
\text { (g/Plant) }\end{array}$ & $\begin{array}{l}\text { Fruits } \\
\text { (g/Plant) }\end{array}$ & $\begin{array}{c}\text { Nutrient Harvest Index } \\
(\%)\end{array}$ \\
\hline \multicolumn{6}{|c|}{ Nitrogen all seasons } \\
\hline Low & $18.73^{\mathrm{b}}$ & $5.26^{\mathrm{a}}$ & $23.99^{b}$ & $26.8^{a}$ & $52.7^{c}$ \\
\hline Middle & $24.33^{b}$ & $4.20^{\mathrm{a}}$ & $28.53^{a b}$ & $57.3^{\mathrm{b}}$ & $66.8^{\mathrm{b}}$ \\
\hline High & $36.89^{\mathrm{a}}$ & $4.83^{\mathrm{a}}$ & $41.72^{\mathrm{a}}$ & $105^{a}$ & $71.4^{\mathrm{a}}$ \\
\hline \multicolumn{6}{|c|}{ Phosphorus all seasons } \\
\hline Low & $1.40^{\mathrm{b}}$ & $0.78^{\mathrm{a}}$ & $2.18^{b}$ & $4.32^{b}$ & $66.5^{\mathrm{b}}$ \\
\hline Middle & $1.85^{\mathrm{ab}}$ & $0.75^{\mathrm{a}}$ & $2.60^{\mathrm{ab}}$ & $8.49^{b}$ & $76.4^{\mathrm{a}}$ \\
\hline High & $2.72^{\mathrm{a}}$ & $1.12^{\mathrm{a}}$ & $3.84^{\mathrm{a}}$ & $15.6^{\mathrm{a}}$ & $80.4^{\mathrm{a}}$ \\
\hline \multicolumn{6}{|c|}{ Potassium all seasons } \\
\hline Low & $9.14^{\mathrm{b}}$ & $3.70^{\mathrm{a}}$ & $12.84^{\mathrm{a}}$ & $28.7^{\mathrm{b}}$ & $68.9^{b}$ \\
\hline Middle & $10.12^{b}$ & $2.77^{\mathrm{a}}$ & $12.89^{\mathrm{a}}$ & $60.2^{b}$ & $82.4^{\mathrm{a}}$ \\
\hline High & $17.00^{\mathrm{a}}$ & $3.23^{\mathrm{a}}$ & $20.23^{a}$ & $122^{\mathrm{a}}$ & $85.9^{\mathrm{a}}$ \\
\hline \multicolumn{6}{|c|}{ Calcium all seasons } \\
\hline Low & $20.85^{c}$ & $3.09^{\mathrm{a}}$ & $23.94^{\mathrm{c}}$ & $6.25^{\mathrm{b}}$ & $20.69^{b}$ \\
\hline Middle & $37.82^{b}$ & $3.09^{\mathrm{a}}$ & $40.91^{b}$ & $12.0^{\mathrm{b}}$ & $22.68^{b}$ \\
\hline High & $58.81^{\mathrm{a}}$ & $3.99^{\mathrm{a}}$ & $62.8^{\mathrm{a}}$ & $25.8^{\mathrm{a}}$ & $29.11^{\mathrm{a}}$ \\
\hline \multicolumn{6}{|c|}{ Magnesium all seasons } \\
\hline Low & $1.95^{\mathrm{b}}$ & $0.67^{\mathrm{a}}$ & $2.62^{\mathrm{a}}$ & $1.81^{\mathrm{b}}$ & $40.95^{\mathrm{b}}$ \\
\hline Middle & $2.67^{\mathrm{ab}}$ & $0.50^{\mathrm{a}}$ & $3.17^{\mathrm{a}}$ & $3.48^{b}$ & $52.49 \mathrm{ab}$ \\
\hline High & $4.22^{\mathrm{a}}$ & $0.56^{\mathrm{a}}$ & $4.78^{\mathrm{a}}$ & $7.45^{\mathrm{a}}$ & $61.0^{\mathrm{a}}$ \\
\hline
\end{tabular}

3.2. The Relationship between Citrus Yield and Nutrient Accumulation or New Shoots Harvest Index in New Shoots

To determine if the yield levels could affect new shoots nutrient concentrations, we further established the relationship between citrus yield and nutrient accumulation or harvest index (Figures 2 and 3). There were significant positive correlations between yield production and the biomass of new shoots $\left(R^{2}=0.61\right), N\left(R^{2}=0.75\right), P\left(R^{2}=0.75\right), K\left(R^{2}=0.63\right), C a\left(R^{2}=0.63\right)$ and $M g$ $\left(R^{2}=0.60\right)$ (Figure 2). There were also significant correlations between citrus yields and the harvest index in new shoots: biomass $\left(\mathrm{R}^{2}=0.56\right)$, and between citrus yields and nutrient concentrations for $\mathrm{N}\left(\mathrm{R}^{2}=0.64\right), \mathrm{P}\left(\mathrm{R}^{2}=0.55\right), \mathrm{K}\left(\mathrm{R}^{2}=0.63\right), \mathrm{Ca}\left(\mathrm{R}^{2}=0.71\right)$ and $\mathrm{Mg}\left(\mathrm{R}^{2}=0.25\right)$ (Figure 3$)$. In addition, the ratio of citrus yield to new shoot harvest index (biomass, nutrient elements) was firstly increased and then decreased (Figure 3).

\subsection{Nutrient Demand per Unit of New Shoots and Fruits under Different Yield Levels}

With the increase in citrus yield levels, the nutrient demand per unit of new shoots showed the largest demand for $\mathrm{N}, \mathrm{K}$ and $\mathrm{Ca}$, followed by $\mathrm{P}$ and $\mathrm{Mg}$, and these nutrient demands also showed a downward trend, ranging from 2.41 to $3.41 \mathrm{~kg} \mathrm{~N} / \mathrm{t} \mathrm{FW,} 0.32$ to $0.43 \mathrm{~kg} \mathrm{P} / \mathrm{t} \mathrm{FW,} 1.46$ to $2.09 \mathrm{~kg} \mathrm{Ca} / \mathrm{t}$ FW and 0.20 to $0.30 \mathrm{~kg} \mathrm{Mg} / \mathrm{t} \mathrm{FW} \mathrm{(Table} \mathrm{4).} \mathrm{With} \mathrm{the} \mathrm{increase} \mathrm{in} \mathrm{citrus} \mathrm{production} \mathrm{level,} \mathrm{there} \mathrm{were} \mathrm{no}$ significant differences in the nutrient requirements per unit of citrus fruit, ranging from 1.74 to $1.78 \mathrm{~kg}$ N/t FW, 0.26 to $0.29 \mathrm{~kg} \mathrm{P} / \mathrm{t} \mathrm{FW,} 1.92$ to $1.96 \mathrm{~kg} \mathrm{~K} / \mathrm{t} \mathrm{FW),} 0.39$ to $0.42 \mathrm{~kg} \mathrm{Ca} / \mathrm{t} \mathrm{FW)} \mathrm{and} 0.11$ to $0.12 \mathrm{~kg} \mathrm{Mg} / \mathrm{t}$ FW. In addition, the nutrient demand per unit of fruits was highest for $\mathrm{N}$ and $\mathrm{K}$, followed by for Ca and $\mathrm{P}$, and least for $\mathrm{Mg}$. 

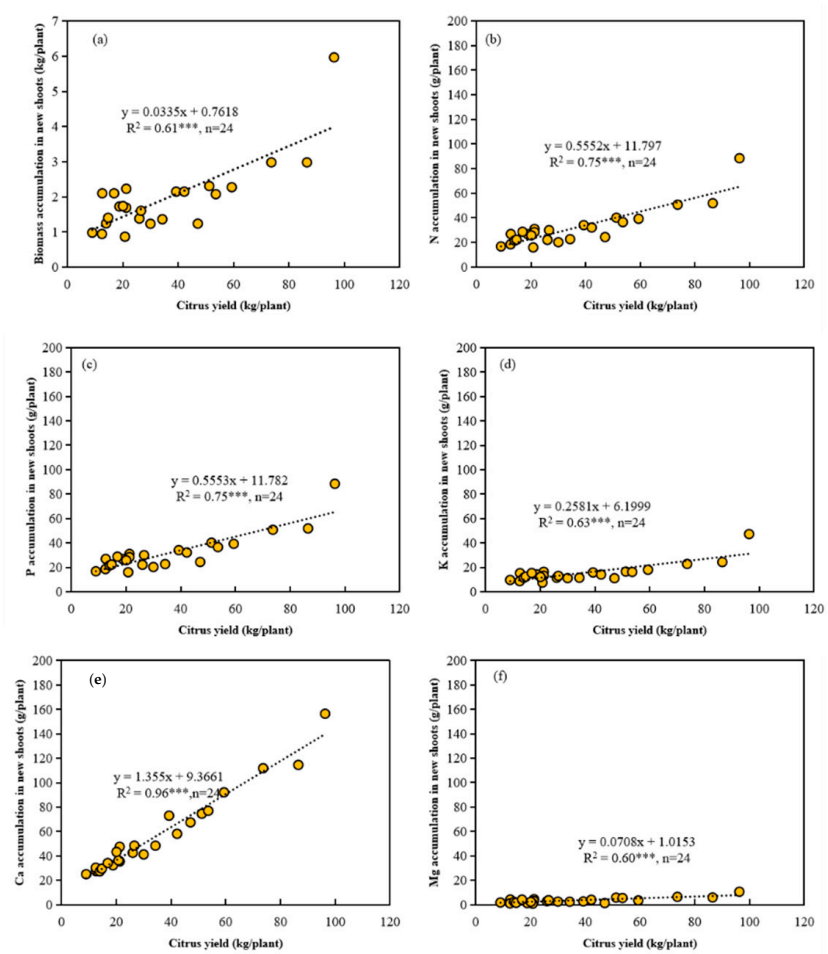

Figure 2. Relationships between citrus yields (kg/plant) and shoot biomass (a), nitrogen (b), phosphorus (c), potassium (d), calcium (e) and magnesium (f) accumulations (g/plant) of citrus trees. The letters denote the panels. ${ }^{* * *}$ indicated significance at $p<0.001$.
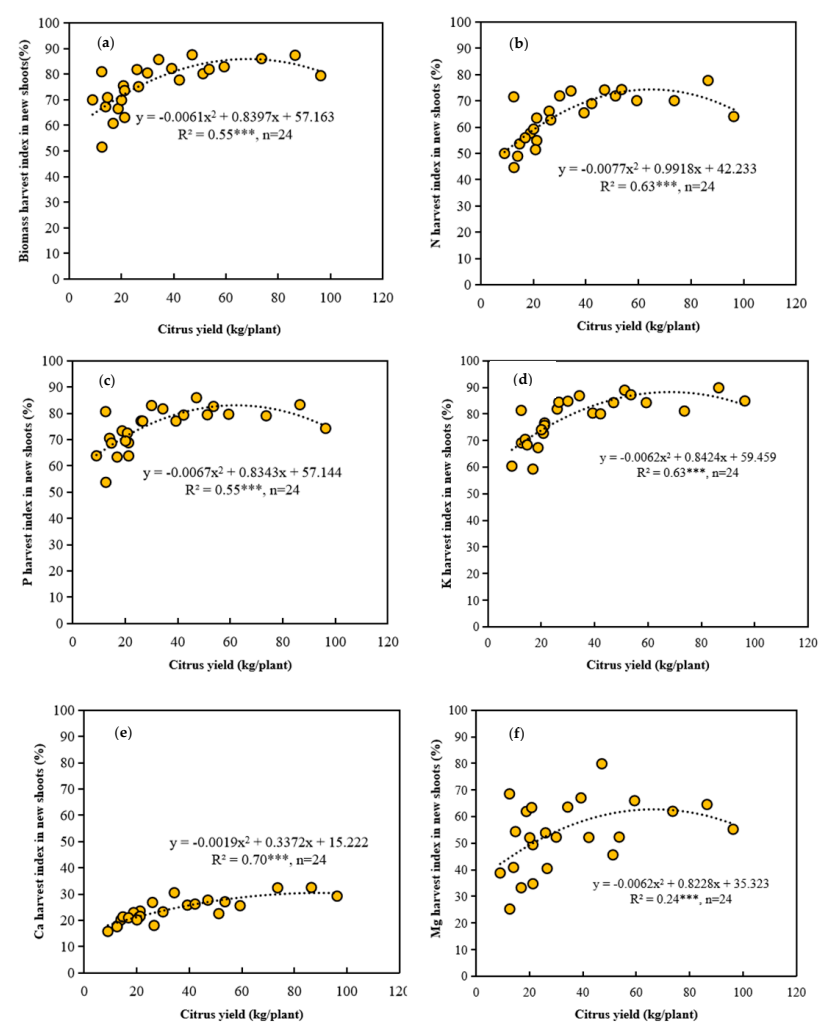

Figure 3. Relationships between citrus yields (kg/plant) and biomass (a), nitrogen (b), phosphorus (c), potassium (d), calcium (e) magnesium (f) harvest in new shoots (\%). The letters denote the panels. $* * *$ indicated significance at $p<0.001$. 
Table 4. Nutrient demand per unit of total new shoots (leaves, twigs and fruits) and fruits under different yield level. Nutrient demand per unit of new shoots $(\mathrm{kg} / \mathrm{t} \mathrm{FW})=$ nutrient accumulation in new shoots/fruit yield; nutrient demand per unit of fruits $(\mathrm{kg} / \mathrm{t} \mathrm{FW})=$ nutrient accumulation in fruit/fruit yield. The different letters $(a-c)$ in the table represent significant differences $(p<0.05)$ among yield-levels.

\begin{tabular}{|c|c|c|c|c|c|}
\hline Yield Level & $\mathbf{N}$ & $\mathbf{P}$ & $\mathbf{K}$ & $\mathrm{Ca}$ & Mg \\
\hline & \multicolumn{5}{|c|}{ Nutrient demand per unit of new shoots $(\mathrm{kg} / \mathrm{t} \mathrm{FW}$} \\
\hline Low & $3.41^{\mathrm{a}}$ & $0.43^{\mathrm{a}}$ & $2.79^{\mathrm{a}}$ & $2.09^{\mathrm{a}}$ & $0.30^{\mathrm{a}}$ \\
\hline Middle & $2.84^{\mathrm{b}}$ & $0.37^{\mathrm{b}}$ & $2.36^{\mathrm{a}}$ & $1.78^{\mathrm{b}}$ & $0.24^{\mathrm{ab}}$ \\
\hline \multirow[t]{2}{*}{ High } & $2.41^{\mathrm{c}}$ & $0.32^{b}$ & $2.29^{a}$ & $1.46^{\mathrm{b}}$ & $0.20^{b}$ \\
\hline & \multicolumn{5}{|c|}{ Nutrient demand per unit of fruits (kg/t FW) } \\
\hline Low & $1.78^{\mathrm{a}}$ & $0.29^{a}$ & $1.94^{\mathrm{a}}$ & $0.42^{\mathrm{a}}$ & $0.12^{\mathrm{a}}$ \\
\hline Middle & $1.87^{\mathrm{a}}$ & $0.28^{\mathrm{a}}$ & $1.92^{\mathrm{a}}$ & $0.39^{\mathrm{a}}$ & $0.11^{\mathrm{a}}$ \\
\hline High & $1.74^{\mathrm{a}}$ & $0.26^{a}$ & $1.96^{\mathrm{a}}$ & $0.42^{\mathrm{a}}$ & $0.12^{\mathrm{a}}$ \\
\hline
\end{tabular}

\section{Discussion}

\subsection{Citrus Production under Different Yield Levels}

Although the age and management of these citrus trees were similar, the yield variation among trees within each orchard was obvious (Figure 1). This phenomenon was also reported in other fruit crops such as pear, apple and olive [23-25]. The major reason for this could be related to the alternate bearing phenomenon [26], which is an important factor affecting the fluctuation of citrus production [27] that is higher in one season than in the next season [8]. In high fruit loading condition, the nutrients and carbohydrates in new shoots were over mobilized into fruit part [28], leading to less nutrient accumulation in new shoots and hindering flower differentiation and yield formation in next season [29]. Thus, it is critical to quantify the nutrient accumulation and distribution in new shoots and fruits of citrus trees with varied yields.

\subsection{Nutrient Requirements of New Shoots of Citrus Are Closely Related to Fruit Yield}

The nutrient concentrations stored in the new shoots and fruits during the developmental stage was closely related to the yield of citrus fruits $[4,15]$. The biomass and nutrient accumulations in citrus shoots were increased with the yield level (Figure 3). Moreover, the increase in biomass of fruit was significantly correlated with the increase in yield level (Table 1), which is consistent with a report on the research of orange fruit [13]. In contrast, the concentrations of each element of N, P, K, Ca and Mg in the fruit were not significantly different among different yield levels (Table 2). This is consistent with the study on some of the nutrients in fruits and vegetables which could even lead to negative correlations between yield and concentrations of minerals [30]. As shown in Table 2, the nutrient concentration in the branches increased with the increase in yield level, except $\mathrm{N}$ and $\mathrm{K}$ and $\mathrm{N}$ and $\mathrm{K}$, which are the most concentrated elements in the fruit. Studies have shown that most of the $\mathrm{N}$ needed by new shoots comes from the transport of old organs [14,31]. In particular, $\mathrm{K}$ would be preferentially translocated to young organs when $\mathrm{K}$ is insufficient for a plant's requirement [32].

\subsection{Distribution of Nutrient Differences between Fruit and New Shoots}

The cumulative proportion of nutrients in the newly developed parts of the fruit firstly increased with the increase in yield and then showed a flat or declining trend, indicating that the new shoots could have served as an indispensable support when the yield was high (Figure 3). The biomass of fruits occupied most of the biomass in the newly developed parts $(65.21 \sim 83.87 \%)$, and accumulations of nutrients in shoots were significantly different from those in fruits, which is similar to the results from another research [33]. This might be due to the fact that the yield of fruit trees was related to the shoot growth, and the quantity and distribution of fruits on the tree were greatly affected by new shoots, which is consistent with previous studies on trees [34]. In the previous peach studies [35], 
the leaf-fruit ratio showed a significant relationship with the dry weight of the fruit. In addition, in the walnut trees, the number of branches retained in trees had a significant impact on the dry weight and yield of the fruit [36]. This implies that all the photosynthetic products in fruit trees are able to flow to the branches with reproductive organs. Except for $\mathrm{Mg}$ and $\mathrm{K}$, the nutrient accumulation of new shoots was significantly higher in high-yield citrus than in middle- and low-yield citrus (Table 3). This might be due to the fact that the supply center of potassium and magnesium shifted from vegetative growth organs to reproductive growth organs during the fruit development stage. The demand for potassium and magnesium in fruits was large, and the demand rate was relatively fast. Only relying on external absorption was insufficient to provide the potassium needed for fruit growth in a timely manner, so it would be rational to provide sufficient potassium and magnesium from shoots to meet the needs of its own fruit growth and development, which are consistent with results in the study of oil-tea Camellia tree and apple [36,37]. In summary, these results show that both the new biomass and nutrient accumulation in citrus have decisive effects on citrus yield productions.

\subsection{Nutrient Composition of New Shoots Has Important Contribution to Yield}

As the yield level increased, more nutrients were distributed in the fruit while reducing the vitality of the tree (Figure 3). Citrus trees should be thus pruned to regulate yield while obtaining high yields to prevent overgrowth of shoots [26]. Because the development of new shoots plays a central role in the complex interaction that determines the nutritional and reproductive growth of woody plants [38], the new shoots of the fruiting tree mainly develop from the top of the branch, and the reproductive behavior strongly influences the number and type of new branches [39]. Researchers have found that the fruit weight in walnut trees is positively correlated with the length and diameter of the annual branch, the diameter of the current branch and the number of nuts in the current branch [36]. Furthermore, the fruit load and morphological characteristics of new shoots have had a certain impact on the potential yield of the current and subsequent seasons in previous research on pears [40], citrus [41] and litchi [42]. Therefore, the nutrient requirement for new annual growth and storage must be considered as a fertilization management priority.

Taken together, the nutrient accumulations in the new shoots play an important role in the yield of citrus. Under different yield levels, there are significant differences in the nutrient's distribution between fruits and non-fruit tissues. Therefore, we believe that the nutrient concentrations of the new shoots do make an important contribution to the yield in the coming year. It is of great significance to further clarify the metabolism, transcription and proteomics mechanisms of citrus fruiting branches and non-fruiting branches under different yield levels.

\section{Conclusions}

The fertilization and management of the eight citrus orchards were similar; however, there were significant differences in yield. The accumulations of nutrients and biomass in the new shoots (leaves and twigs) of the citrus trees are the important basis for citrus yield. However, with the increase in yield level, the accumulation of nutrient elements in new shoots increased, and Ca mainly accumulated in new leaves, while N, P and K were mainly accumulated in fruits. Furthermore, with the increase in yield level, the nutrient requirements per unit of new shoots gradually decreased, but the nutrient demand per unit of fruits remained almost stable, indicating that more nutrients were distributed into fruit tissues. Taken together, the nutrient accumulations in the new shoots play an important role in the yield of citrus fruits. Under different yield levels, there are significant differences in the nutrient's distribution between fruits and non-fruit tissues. Therefore, we believe that the nutrient accumulations in the new shoots do make an important contribution to the yield in the coming year. Thus, this study will increase our understanding of citrus with different yields, especially nutrient composition and yield of citrus, which will further help to optimize fertilization management of citrus orchards. 
Author Contributions: Z.F., H.X., Y.L., Y.W., H.Z. and W.L. conducted research work, collected and analyzed the data and prepared the manuscript; X.H., J.W., X.S. and Y.Z. designed, supervised this study, revised and approved this manuscript for publication. All authors have read and agreed to the published version of the manuscript.

Funding: This work was supported by the National Key Research and Development Project of China (2016YFD0200104) and the National Natural Science Foundation of China (31801932).

Conflicts of Interest: The authors declare no conflict of interest.

\section{Appendix A}

Table A1. The fresh weight (FW) in newly development parts of citrus trees with respect to yield level. The different letters $(\mathrm{a}, \mathrm{b})$ in the table represent significant differences $(p<0.05)$ among yield-levels.

\begin{tabular}{cccccc}
\hline \multirow{2}{*}{ Yield-Level } & Leaves & Twigs & $\begin{array}{c}\text { New } \\
\text { Shoots }\end{array}$ & Fruits & Total \\
\cline { 2 - 6 } & $\mathbf{( k g / P l a n t )}$ & $\mathbf{( k g / P l a n t )}$ & $\mathbf{( k g / P l a n t )}$ & $\mathbf{( k g / P l a n t )}$ & $\mathbf{( k g / P l a n t )}$ \\
\hline Low & $2.82^{\mathrm{b}}$ & $1.08^{\mathrm{a}}$ & $3.9^{\mathrm{b}}$ & $15.0^{\mathrm{b}}$ & $18.9^{\mathrm{b}}$ \\
Middle & $3.55^{\mathrm{ab}}$ & $1.25^{\mathrm{a}}$ & $4.8^{\mathrm{ab}}$ & $30.9^{\mathrm{b}}$ & $35.7^{\mathrm{b}}$ \\
High & $4.96^{\mathrm{a}}$ & $1.69^{\mathrm{a}}$ & $6.65^{\mathrm{a}}$ & $60.1^{\mathrm{a}}$ & $66.8^{\mathrm{a}}$ \\
\hline
\end{tabular}

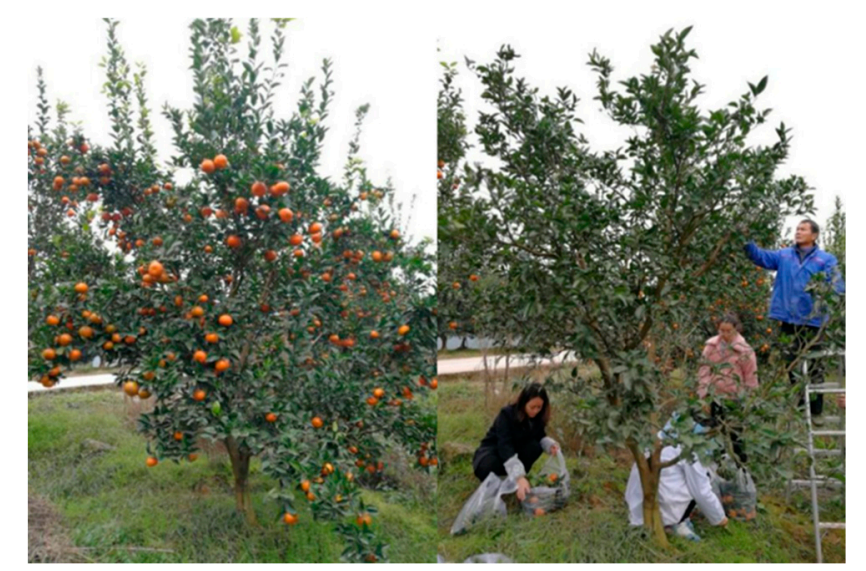

Figure A1. Collecting citrus fruits and recording data.

\section{References}

1. Amiri, M.E.; Fallahi, E.; Golchin, A. Influence of foliar and ground fertilization on yield, fruit quality, and soil, leaf, and fruit mineral nutrients in apple. J. Plant Nutr. 2008, 31, 515-525. [CrossRef]

2. Quaggio, J.A.; Souza, T.R.; Bachiega Zambrosi, F.C.; Marcelli Boaretto, R.; Mattos, D. Nitrogen-fertilizer forms affect the nitrogen-use efficiency in fertigated citrus groves. J. Plant Nutr. Soil Sci. 2014, 177, 404-411. [CrossRef]

3. Tsakelidou, K.; Papanikolaou, X.; Karagiannidis, N. Fruit production and nutrient status in grapefruit on five rootstocks. J. Plant Nutr. 2007, 30, 995-1004. [CrossRef]

4. Liu, G.; Chen, Y.; He, X.; Yao, F.; Guan, G.; Zhong, B.; Zhou, G. Seasonal changes of mineral nutrients in the fruit of navel orange plants grafted on trifoliate orange and citrange. Sci. Hortic. 2020, 264, 109156. [CrossRef]

5. Zambrosi, F.C.B.; Mesquita, G.L.; Tanaka, F.A.O. Assessment of leaf ultrastructure offers insights into mechanisms regulating sugarcane performance under low-phosphorus stress. Acta Physiol. Plant. 2020, 42, 1-7. [CrossRef]

6. Hippler, F.W.R.; Boaretto, R.M.; Dovis, V.L.; Quaggio, J.A.; Azevedo, R.A.; Mattos, D., Jr. Oxidative stress induced by $\mathrm{Cu}$ nutritional disorders in Citrus depends on nitrogen and calcium availability. Sci. Rep. 2018, 8, 1641. [CrossRef] 
7. Ye, X.; Chen, X.F.; Cai, L.Y.; Lai, N.W.; Deng, C.L.; Guo, J.X.; Yang, L.T.; Chen, L.S. Molecular and physiological mechanisms underlying magnesium-deficiency-induced enlargement, cracking and lignification of Citrus sinensis leaf veins. Tree Physiol. 2020, 40, 1277-1291. [CrossRef] [PubMed]

8. Moreira, R.A.; Ramos, J.D.; Cruz, M.D.C.M.D.; Pantoja, L.D.A.; Santos, A.S.D. Carbohydrate levels in the leaves and production consistency of the Ponkan tangerine when thinned out with Ethephon1. Artig. Cientifico 2013, 44, 571-577.

9. Martinez-Alcantara, B.; Iglesias, D.J.; Reig, C.; Mesejo, C.; Agusti, M.; Primo-Millo, E. Carbon utilization by fruit limits shoot growth in alternate-bearing citrus trees. J. Plant Physiol. 2015, 176, 108-117. [CrossRef]

10. Yang, M.; Long, Q.; Li, W.; Wang, Z.; He, X.; Wang, J.; Wang, X.; Xiong, H.; Guo, C.; Zhang, G.; et al. Mapping the environmental cost of a typical citrus-producing county in China: Hotspot and optimization. Sustainability 2020, 12, 1827. [CrossRef]

11. Martínez-Fuentes, A.; Mesejo, C.; Muñoz-Fambuena, N.; Reig, C.; González-Mas, M.C.; Iglesias, D.J.; Primo-Millo, E.; Agustí, M. Fruit load restricts the flowering promotion effect of paclobutrazol in alternate bearing Citrus spp. Sci. Hortic. 2013, 151, 122-127. [CrossRef]

12. Li, Y.J.; Yang, M.; Zhang, Z.Z.; Li, W.L.; Guo, C.Y.; Chen, X.P. An ecological research on potential for zero-growth of chemical fertilizer use in citrus production in China. Ekoloji 2019, 28, 1049-1059.

13. Roccuzzo, G.; Zanotelli, D.; Allegra, M.; Giuffrida, A.; Torrisi, B.F.; Leonardi, A.; Quiñones, A.; Intrigliolo, F.; Tagliavini, M. Assessing nutrient uptake by field-grown orange trees. Eur. J. Agron. 2012, 41, 73-80. [CrossRef]

14. Roccuzzo, G.; Scandellari, F.; Allegra, M.; Torrisi, B.; Stagno, F.; Mimmo, T.; Zanotelli, D.; Gioacchini, P.; Millard, P.; Tagliavini, M. Seasonal dynamics of root uptake and spring remobilisation of nitrogen in field grown orange trees. Sci. Hortic. 2017, 226, 223-230. [CrossRef]

15. Lu, Z.-J.; Yu, H.-Z.; Mi, L.-F.; Liu, Y.-X.; Huang, Y.-L.; Xie, Y.-X.; Li, N.-Y.; Zhong, B.-L. The effects of inarching Citrus reticulata Blanco var. tangerine on the tree vigor, nutrient status and fruit quality of Citrus sinensis Osbeck 'Newhall' trees that have Poncirus trifoliata (L.) Raf. as rootstocks. Sci. Hortic. 2019, 256, 108600. [CrossRef]

16. Menino, M.R.; Carranca, C.; de Varennes, A. Distribution and remobilization of nitrogen in young non-bearing orangetrees grown under mediterranean conditions. J. Plant Nutr. 2007, 30, 1083-1096. [CrossRef]

17. Martínez-Alcántara, B.; Quiñones, A.; Legaz, F.; Primo-Millo, E. Nitrogen-use efficiency of young citrus trees as influenced by the timing of fertilizer application. J. Plant Nutr. Soil Sci. 2012, 175, 282-292. [CrossRef]

18. Li, W.; Yang, M.; Wang, J.; Wang, Z.; Fan, Z.; Kang, F.; Wang, Y.; Luo, Y.; Kuang, D.; Chen, Z.; et al. Agronomic responses of major fruit crops to fertilization in China: A Meta-Analysis. Agronomy 2019, 10, 15. [CrossRef]

19. Wu, B.H.; Mimoun, M.B.; Génard, M.; Lescourret, F.; Besset, J.; Bussi, C. Peach fruit growth in relation to the leaf-to-fruit ratio, early fruit size and fruit position. J. Hortic. Sci. Biotechnol. 2015, 80, 340-345. [CrossRef]

20. Yang, J.; Zhang, J.; Li, J.; Zheng, Y.; Lv, Q.; Xie, R.; Ma, Y.; Deng, L.; He, S.; Yi, S. Effects of nitrogen application levels on nutrient, yield and quality of Tarocco blood orange and soil physicochemical properties in the three gorges area of Chongqing. Sci. Agric. Sin. 2019, 52, 893-908.

21. Buresh, R.J.; Austin, E.R.; Craswell, E.T. Analytical methods in 15N research. Fertil. Res. 1982, 3, 37-62. [CrossRef]

22. Zhang, Y.Q.; Pang, L.L.; Yan, P.; Liu, D.Y.; Zhang, W.; Yost, R.; Zhang, F.S.; Zou, C.Q. Zinc fertilizer placement affects zinc content in maize plant. Plant Soil 2013, 372, 81-92. [CrossRef]

23. Fan, S.; Gao, X.; Gao, C.; Yang, Y.; Zhu, X.; Feng, W.; Li, R.; Tahir, M.M.; Zhang, D.; Han, M.; et al. Dynamic Cytosine DNA Methylation Patterns Associated with mRNA and siRNA Expression Profiles in Alternate Bearing Apple Trees. J. Agric. Food Chem. 2019, 67, 5250-5264. [CrossRef]

24. KaÇAl, E. Crop Load Regulation with Chemical Thinners in Deveci Pear (Pyrus Communis L.). Appl. Ecol. Environ. Res. 2018, 16, 7203-7212.

25. Albarracín, V.; Hall, A.J.; Searles, P.S.; Rousseaux, M.C. Responses of vegetative growth and fruit yield to winter and summer mechanical pruning in olive trees. Sci. Hortic. 2017, 225, 185-194. [CrossRef]

26. Mesejo, C.; Martínez-Fuentes, A.; Reig, C.; Balasch, S.; Primo-Millo, E.; Agustí, M. Mechanical pruning attenuates alternate bearing in 'Nadorcott' mandarin. Sci. Hortic. 2020, 261, 108993. [CrossRef] 
27. Adouli, B.; Zamani, Z.; Fattahi-Mohgadam, M.R.; Golein, B.; Rezaei, K. Effects of alternate bearing and 2, 4-D application on fruit growth pattern, abscission enzymes activity, ACC content of calyx and carbohydrates partitioning of fruits in Satsuma mandarin (Citrus unshiu Marc.) cv. Miyagawa. Sci. Hortic. 2018, 238, 58-65. [CrossRef]

28. Miyata, A.; Hashimoto, K. Effects of intentional alternate bearing methods on tree growth, yield and fruit quality in young tree of 'Aoshima unshiu' satsuma mandarin (Citrus unshiu Marc.). J. Jpn. Soc. Hort. Sci. 2002, 71, 789-795. [CrossRef]

29. Rebolledo, A.; Garcia-Luis, A.; Guardiola, J.L.; Monerri, C. Effect of 2,4-D on fruit sugar accumulation and invertase activity in sweet orange cv. Salustiana. Aust. J. Crop Sci. 2015, 9, 105-111.

30. Davis, D.R. Declining Fruit and Vegetable Nutrient Composition: What Is the Evidence? Hortscience 2009, 1, 15-19. [CrossRef]

31. Millard, P.; Grelet, G.A. Nitrogen storage and remobilization by trees: Ecophysiological relevance in a changing world. Tree Physiol. 2010, 30, 1083-1095. [CrossRef] [PubMed]

32. Jiang, F.; Li, C.; Jeschke, W.D.; Zhang, F. Effect of top excision and replacement by 1-naphthylacetic acid on partition and flow of potassium in tobacco plants. J. Exp. Bot. 2001, 52, 2143-2150. [CrossRef] [PubMed]

33. Mattos, D.; Graetz, D.; Alva, A.K. Biomass distribution and nitrogen-15 partitioning in citrus trees on a sandy entisol. Soil Sci. Soc. Am. J. 2003, 67, 555-563. [CrossRef]

34. Hosomi, A. Relationship Between Shoot Growth and Fruit Production of 'Masui Dauphine' and 'Houraishi' Fig Trees at Various Plant Densities. Hortic. J. 2020, 89, 375-383. [CrossRef]

35. Richard, R.P. Peach fruit weight, yield, and crop value are affected by number of fruiting shoots per tree. Hortscience 2003, 38, 512-514.

36. Valdebenito, D.; Farías, D.; Lampinen, B.; Tixier, A.; Zwieniecki, M.; Saa, S. The position in the canopy and the bearing status of 1-year-old shoots affect the bearing potential and morphology of current-year shoots in walnuts (Juglans regia L.) cv. Chandler. Trees Struct. Funct. 2018, 32, 1267-1277. [CrossRef]

37. Cao, Y.; Ren, H.; Lin, P. Research on Annual Changes of Nitrogen, Phosphorous, Potassium Absorption and Accumulation in Oil-tea Camellia Tree. For. Res. 2012, 25, 442-448.

38. Casero, T.; Torres, E.; Alegre, S.; Recasens, I. Macronutrient accumulation dynamics in apple fruits. J. Plant Nutr. 2017, 40, 2468-2476. [CrossRef]

39. Sønsteby, A.; Roos, U.M.; Heide, O.M. Effects of biennial cropping and controlled shoot density on yield performance and fruit quality in red raspberry (Rubus idaeus L.). J. Hortic. Sci. Biotechnol. 2018, 94, 243-250.

40. Zegbe, J.A.; Serna-Pérez, A.; Mena-Covarrubias, J. Mineral nutrition enhances yield and affects fruit quality of 'Cristalina' cactus pear. Sci. Hortic. 2014, 167, 63-70. [CrossRef]

41. Lliso, I.; Forner, J.B.; Talon, M. The dwarfing mechanism of citrus rootstocks F\&A 418 and \#23 is related to competition between vegetative and reproductive growth. Tree Physiol. 2004, 24, 225-232. [PubMed]

42. Hieke, S.; Menzel, C.M.; Doogan, V.J.; Lüdders, P. The relationship between fruit and leaf growth in lychee (Litchi chinensis Sonn.). J. Hortic. Sci. Biotechnol. 2002, 77, 320-325. [CrossRef]

Publisher's Note: MDPI stays neutral with regard to jurisdictional claims in published maps and institutional affiliations.

(C) 2020 by the authors. Licensee MDPI, Basel, Switzerland. This article is an open access article distributed under the terms and conditions of the Creative Commons Attribution (CC BY) license (http://creativecommons.org/licenses/by/4.0/). 